\title{
Use of bronchoscopy in the diagnosis of infection in the immunocompromised host
}

Although studies have shown the usefulness of individual methods such as bronchoalveolar lavage (BAL) in diagnosing pneumonia, ${ }^{12}$ the bronchoscope itself provides access to lower respiratory secretions and tissue in a number of ways.

Bronchoscopy allows us to sample the lower respiratory tract by (1) bronchial washings, which are a pooling of the secretions retrieved during bronchoscopy; (2) BAL, during which fluid is collected by low pressure suction after a fairly large volume $(100-240 \mathrm{ml})$ of saline is instilled and aspirated at low pressure with the bronchoscope wedged in a distal airway; (3) bronchial brushing, during which a catheter is advanced into a specific area of the lung and samples are taken; and (4) biopsy, in which a small amount of tissue from the airway (bronchial biopsy) or alveolar space (transbronchial biopsy) is sampled. These techniques are complementary for diagnosing many infections, although one or other procedure may be better suited for individual infections. For example, bronchial brushing and biopsies increase the chances of bleeding during the procedure and are not usually performed in thrombocytopenic patients, ${ }^{3}$ and transbronchial biopsy has a significantly higher risk of causing pneumothorax than bronchoscopy alone, although the risk is still less than $10 \% .^{3-5}$

In assessing the various techniques one has to consider that certain infections may be more likely to be diagnosed by one technique than by another. The techniques sample different portions of the airways and thus what they diagnose depends somewhat on where the microorganism resides. For example, Pneumocystis carinii is present in alveoli and is best diagnosed by techniques which sample the alveoli (BAL) or allow for direct pathological examination (transbronchial biopsy). ${ }^{4}$ Bronchial brushing will not reach the alveoli and therefore is not going to be diagnostic for most cases of $P$ carinii. On the other hand, Mycobacterium tuberculosis is present in cavities and in the airways; BAL may not sample a thin walled cavity easily, while bronchial washing samples the airway secretions better than does BAL. ${ }^{6}$

Another concern is the significance of a particular pathogen. The recovery of some organisms from any respiratory secretion is clearly associated with pneumonia (for example, $M$ tuberculosis or $P$ carinii), ${ }^{1246}$ while other organisms such as Candida and Streptococcus pneumoniae may colonise the upper airway without necessarily causing disease. In the latter case pathological changes need to be shown in the lower respiratory tract by cytological or histopathological examination, or the organism must be recovered at higher concentrations in the lower than the upper airway. ${ }^{7}$

In the following sections individual infections and how they are best diagnosed by bronchoscopy are discussed.

\section{Pneumocystis pneumonia}

For patients with possible pneumocystis pneumonia bronchoscopy is the procedure with the highest yield and the lowest risk. Diagnosis of pneumocystis pneumonia by induced sputum has been proposed as an alternative method with lower cost and reasonable sensitivity. ${ }^{8-11}$ However, the cost of processing the specimen has to be included, and a laboratory highly familiar with the correct identification is needed; there is also the complication of multiple infections being present. In our experience of over $400 \mathrm{HIV}$ patients infected with pneumocystis pneumonia an additional pathogen has been found in over $15 \%$ of cases.

There have been several comparisons of the different methods of diagnosing pneumocystis pneumonia by bronchoscopy (table 1). Bronchial brushing has the lowest diagnostic yield, significantly less than either BAL or transbronchial biopsy. This is probably because the alveolar sample is diluted with upper airway secretions which have very few organisms.

Transbronchial biopsy consistently has the highest yield of organisms. To be diagnostic, several biopsies with alveolar tissue have to be obtained. Rarely is $P$ carinii seen in bronchial biopsies ${ }^{17}$ and, because of the need for alveolar sampling, there is a significant risk of pneumothorax developing. This is a considerable problem in patients with pneumocystis pneumonia who already have an increased risk for spontaneous pneumothoraces. ${ }^{1819}$ In a study of over $100 \mathrm{HIV}$ infected patients undergoing transbronchial biopsy, $9 \%$ had pneumothoraces and over half of these required chest drainage. ${ }^{4}$

Bronchoalveolar lavage appears to have a sufficiently high diagnostic yield, good specificity, and relatively low morbidity compared with transbronchial biopsy. It is now the procedure of choice for diagnosing pneumocystis pneumonia, ${ }^{20}$ with most centres no longer performing transbronchial biopsies. In addition to identifying the organism, BAL provides additional information including an assessment of the inflammatory response of the lung. Patients with pneumocystis pneumonia have increased levels of neutrophils in their BAL fluid, with increased albumin permeability and a poorer prognosis. ${ }^{2122}$ Bronchoalveolar lavage can also estimate the relative burden of $P$ carinii infection in the lung, ${ }^{2324}$ and this has been used to determine the response to drug treatment. ${ }^{25}$

Jules-Elysee and colleagues ${ }^{12}$ reported that BAL may have only a $60 \%$ diagnostic yield in patients receiving treatment with aerosolised pentamidine; in such patients the transbronchial biopsy significantly enhances diagnostic yield. Since aerosolised pentamidine is associated with a significant failure rate, ${ }^{26}$ there is concern that, in the HIV patient with possible pneumocystis pneumonia, the diagnosis may be missed if only BAL is performed. We $\mathrm{e}^{27}$ and others ${ }^{28-30}$ have shown that lavaging areas with most

Table 1 Relative efficacy (\%) of various bronchoscopic techniques for diagnosing Pneumocystis carinii pneumonia in patients with AIDS

\begin{tabular}{|c|c|c|c|c|c|}
\hline Reference & $\begin{array}{l}\text { No. of } \\
\text { cases }\end{array}$ & Brushing & Washing & $\begin{array}{l}\text { Bronchoalveolar } \\
\text { lavage }\end{array}$ & Biopsy \\
\hline $\begin{array}{l}\text { Broaddus et } a l^{4} \\
\text { Jules-Elysee } \text { et } a l^{12}\end{array}$ & 117 & & & 89 & 93 \\
\hline $\begin{array}{l}\text { No pentamidine } \\
\text { Pentamidine }\end{array}$ & 31 & & & 100 & 84 \\
\hline prophylaxis & 21 & & & 62 & 81 \\
\hline $\begin{array}{l}\text { Gal et al }{ }^{13} \text { । } \\
\text { Baughman et } \text { al }^{14}\end{array}$ & $\begin{array}{l}20 \\
59\end{array}$ & 79 & 70 & $\begin{array}{l}95 \\
97\end{array}$ & 94 \\
\hline $\begin{array}{l}\text { Baughman et al } \\
\text { Coleman et al } \text { l }^{15}\end{array}$ & $\begin{array}{l}59 \\
22\end{array}$ & 39 & 55 & & 79 \\
\hline Stover et al ${ }^{16}$ & 39 & & 41 & 85 & 88 \\
\hline Mones et al & 95 & 57 & 59 & & 97 \\
\hline Total & 404 & 58 & 58 & 90 & 91 \\
\hline
\end{tabular}


infiltrate on the chest radiograph can enhance the diagnostic yield. There are generally about twice as many organisms in the upper lobe than in the middle lobe of patients with pneumocystis pneumonia. ${ }^{27} 29$

\section{Viral infections}

In the immunocompetent patient cytomegalovirus (CMV) pneumonia is rare. Even in patients with $\mathrm{CMV}$ viraemia resulting from post transfusion infection pneumonia is uncommon. However, in the immunocompromised patient CMV can be dangerous, even fatal, particularly in patients with bone marrow transplantation. The infection usually occurs 6-8 weeks after the transplantation. ${ }^{31}{ }^{32}$ The patient may develop acute pneumonia or a more indolent infection, which may lead to a graft versus host reaction in the lung. ${ }^{33}$ This pneumonitis can be progressive and may not respond to antiviral treatment such as ganciclovir alone..$^{34}$ Because of the poor prognosis of patients with advanced disease, attempts have been made to make an early, precise diagnosis in these patients.

The highest diagnostic yield for CMV infection is from the BAL fluid. Unfortunately it may be several weeks before final culture results are available, but more rapid results can be obtained by identifying antigenic changes in infected cells using BAL or bronchial washing. ${ }^{356}$ These will identify $>80 \%$ of specimens which subsequently will be culture positive, and can be enhanced by the shell vial centrifugation technique with results available within one day. .53738

In patients with solid organ transplants the presence of CMV in the lower respiratory tract is less significant, but is still a problem. ${ }^{31} 3940$ Lung transplant patients can develop a reaction which is equivalent to the graft versus host reaction seen in bone marrow transplant patients. It has been proposed that $\mathrm{CMV}$ infection is responsible for the bronchiolitis obliterans associated with chronic rejection. ${ }^{41}$ In other solid organ transplants CMV infection can range from mild to severe. ${ }^{4042}$

In the HIV infected population CMV is commonly recovered from culture of the BAL fluid specimen. ${ }^{43-45}$ This is associated with more severe hypoxaemia but there is no evidence of any short term (less than three weeks) increase in mortality for HIV positive patients with CMV infection. However, necropsy studies have shown that patients do die from CMV pneumonitis. ${ }^{46}$

To determine whether a patient has CMV pneumonia rather than just infection, the most specific method is transbronchial biopsy looking for cytopathological changes with an associated pneumonitis. ${ }^{39}$ The examination of BAL fluid and wash specimens may also demonstrate more advanced lower respiratory infection, but may not be as specific as the transbronchial biopsy specimen. Cytological diagnosis can be performed on the brushings, washings, or BAL fluid specimens, with BAL fluid having a higher diagnostic yield for CMV; however, in our laboratory BAL and washing are complementary. In situ hybridisation can also be used to detect CMV genomic material in individual cells, ${ }^{47}$ but it is not clear whether these changes correspond to CMV pneumonitis.

Herpes simplex virus (HSV) is not a significant pathogen in immunocompromised patients but it can cause pneumonia ${ }^{48}$ Reactivation of upper airway herpes virus is not uncommon during stress. In patients with the adult respiratory distress syndrome (ARDS) the recovery of HSV from bronchoscopy washes was associated with a higher rate of mortality. ${ }^{49}$ A subsequent study showed that prophylactic acyclovir could reduce the incidence of HSV infection but it did not change the morbidity or mortality of the underlying ARDS. ${ }^{50}$ Cytological examination speci- mens can be helpful, and lesions suspicious for HSV in the airways can be specifically diagnosed by bronchial brushing and subsequent Papanicolaou staining to show giant cells with inclusion bodies.

The recovery of other viruses by bronchoscopy has occasionally been reported. In a study of over $1000 \mathrm{BAL}$ fluid samples cultured for viruses at our institution, one or more viruses were identified from over $50 \% .^{51}$ The most common were CMV and HSV, comprising 550 cases, and other viruses included influenza, parainfluenza, adenovirus, and rhinovirus. Only the influenza and adenovirus appeared to be associated with significant morbidity.

\section{Tuberculosis}

Although sputum sampling remains the procedure of choice for diagnosing tuberculosis, ${ }^{52}$ the use of bronchoscopy has become common, especially in immunocompromised patients. Bronchial washing, BAL, and transbronchial biopsy have all been studied. ${ }^{6534}$ The techniques appear complementary, although my personal feeling is that bronchial washing provides the safest, highest diagnostic yield. In the study by Wallace et $a l^{54}$ transbronchial biopsy significantly enhanced the diagnostic yield from bronchial washing alone. In our study of 50 patients with $M$ tuberculosis infection we rarely found it necessary to perform a transbronchial biopsy; seven patients had a positive wash specimen and negative BAL fluid specimen, and only one patient had the reverse. ${ }^{6}$ The higher yield from bronchial washing in our study may have been because of the larger sample obtained, as the washing included fluid not aspirated during the BAL technique itself. In patients with cavities BAL may have a poor result because of airway collapse during aspiration; however, lavage itself will induce cough and the subsequent specimen should contain plenty of organisms (the ultimate in saline induced sputum).

\section{Fungal infections}

Histoplasmosis, coccidiomycosis, and cryptococcus have all been isolated from bronchoscopy specimens. ${ }^{6556}$ The overall diagnostic yield for these pathogens by culture, however, may be less than that obtained in tuberculosis.

The bronchial washing specimen has been shown to have a good yield in patients with fungal infection. ${ }^{6557}$ Cultures are more sensitive than direct cytological examination. The BAL fluid specimen may increase the yield for pathogens, both for the BAL itself and by increasing the volume of the wash specimen. Transbronchial biopsy can

Table 2 Comparison of various bronchoscopic techniques to identify individual organisms on a scale of $0-3$

\begin{tabular}{|c|c|c|c|c|c|}
\hline Organism & Washing & Brushing & $\begin{array}{l}\text { Broncho- } \\
\text { alveolar } \\
\text { lavage }\end{array}$ & Biopsy & References \\
\hline Pneumocystis carinii & 2 & 1 & 3 & 3 & $4,12,13,14,27$ \\
\hline $\begin{array}{l}\text { Viral } \\
\text { Cytomegalovirus } \\
\text { Other viral }\end{array}$ & $\begin{array}{l}1 \\
1\end{array}$ & $\begin{array}{l}1 \\
1\end{array}$ & $\begin{array}{l}3 \\
2\end{array}$ & $\begin{array}{l}2 \\
1\end{array}$ & $\begin{array}{l}36,37,38,45 \\
51\end{array}$ \\
\hline Tuberculosis & 3 & 0 & 2 & 3 & $6,53,54$ \\
\hline $\begin{array}{l}\text { Fungal } \\
\text { Candida } \\
\text { Aspergillus } \\
\text { Histoplasmosis, } \\
\text { blastomycosis, } \\
\text { cryptococcus, } \\
\text { coccidiomycosis }\end{array}$ & $\begin{array}{l}0 \\
0\end{array}$ & $\begin{array}{l}0 \\
0\end{array}$ & $\begin{array}{l}1 \\
1\end{array}$ & $\begin{array}{l}2 \\
2\end{array}$ & $6,55,56,57$ \\
\hline $\begin{array}{l}\text { Bacterial } \\
\text { Routine bacterial } \\
\text { Legionella } \\
\text { Nocardia }\end{array}$ & $\begin{array}{l}0 \\
1 \\
3\end{array}$ & $\begin{array}{l}3^{*} \\
1 \\
\text { ND }\end{array}$ & $\begin{array}{l}2 \\
2 \\
2\end{array}$ & $\begin{array}{l}0 \\
1 \\
\text { ND }\end{array}$ & $\begin{array}{l}7,63,69,75 \\
78,79 \\
55,80\end{array}$ \\
\hline
\end{tabular}

$\mathrm{ND}=$ Not determined

* Protected brush. 
Table 3 Relative risk of infection based on underlying condition of host on scale of $0-3$

\begin{tabular}{|c|c|c|c|c|c|}
\hline & \multicolumn{3}{|l|}{$H I V$ infected } & \multicolumn{2}{|c|}{ Transplantation } \\
\hline & $>250$ CD4 lymphocytes $/ \mathrm{mm}^{3}$ & $<250 \mathrm{CD} 4$ lymphocytes $/ \mathrm{mm}^{3}$ & Neutropenic & Solid organ & Bone marrow \\
\hline $\begin{array}{l}\text { Pneumocystis carinii } \\
\text { Mycobacterium tuberculosis } \\
\text { Routine bacterial } \\
\text { Legionella } \\
\text { Candida/Aspergillus } \\
\text { Histoplasmosis, coccidiomycosis, cryptococcus } \\
\text { Cytomegalovirus }\end{array}$ & $\begin{array}{l}1 \\
3 \\
2 \\
0 \\
0 \\
2 \\
1\end{array}$ & $\begin{array}{l}3 \\
1 \\
1 \\
0 \\
0 \\
3 \\
2\end{array}$ & $\begin{array}{l}2 \\
1 \\
2 \\
0 \\
2 \\
2 \\
2\end{array}$ & $\begin{array}{l}2 \\
1 \\
2 \\
2 \\
0 \\
1 \\
2\end{array}$ & $\begin{array}{l}1 \\
1 \\
2 \\
2 \\
2 \\
1 \\
3\end{array}$ \\
\hline
\end{tabular}

define whether there is fungus within the lower respiratory tract but the amount of tissue available for culture is small. In an animal model of histoplasmosis BAL was found to be more sensitive than transbronchial biopsy in diagnosing pulmonary histoplasmosis; ${ }^{56}$ thus, there appears to be a limited role for transbronchial biopsy in these infections.

Another option for rapid diagnosis of fungi is to look for antigens. Cryptococcal antigen is detectable in the BAL fluid, ${ }^{58}$ a titre of $\geqslant 1: 8$ being associated with positive culture. A histoplasmosis antigen has also been reported in the BAL fluid, ${ }^{59}$ but this test is not as widely available as the cryptococcal antigen test. The use of these antigen tests should be selective. We examine for cryptococcal antigen in our HIV infected patients as they are at high risk for this since infection and the test can be run in less than one hour.

For Candida and Aspergillus infections there are two issues. Firstly, the organisms are less sensitive to cell mediated immunity and are more likely to be controlled by neutrophils, so they are rarely encountered unless there has been neutropenia, use of broad spectrum antibiotics, diabetes, or treatment with corticosteroids. Here the concern is that Candida or Aspergillus may become invasive with associated significant morbidity and mortality. Secondly, in diagnosing candidal or aspergillus pneumonia the recovery of pathogen by bronchial washing or BAL is insufficient. If a large number of fungi are seen in a BAL fluid specimen, one could argue that the infection is more than upper airway colonisation, ${ }^{60}$ but this assumption has not been rigorously tested. A more specific diagnosis can be made by examining a transbronchial biopsy, as the presence of invasive organisms confirms infection. ${ }^{61} \mathrm{Un}$ fortunately, many patients with possible infection with Aspergillus are not only neutropenic but thrombocytopenic, and thus cannot undergo a biopsy.

\section{Bacterial pneumonia}

Historically, bronchoscopy was considered a poor method of diagnosing bacterial pneumonia ${ }^{62}$ because the lower respiratory tract becomes contaminated during the bronchoscopy itself. The upper airway secretions contaminate the bronchoscope, as well as contaminating the lower respiratory system. The culturing of bronchial washings is therefore not useful.

To circumvent the upper respiratory contamination two methods are used. The first is the protected specimen brush first described by Wimberley et al. ${ }^{63}$ Unfortunately this technique does not always provide a sterile sample in the uninfected host, and quantitation of the organisms recovered is necessary to determine whether the organism is an upper respiratory contaminant or represents lower respiratory infection. ${ }^{64}{ }^{65}$ The specimen is resuspended in a known volume of fluid and cultures are performed in a semiquantitative manner. Using the semiquantitative cutoff of $\geqslant 10^{3}$ colony forming units $(\mathrm{cfu}) / \mathrm{ml}$ of resuspended specimen, sensitivity and specificity of over $80 \%$ are achieved in patients not receiving antibiotics. ${ }^{66}$ This includes patients with community acquired pneumonia, ${ }^{67}$ sickle cell disease, ${ }^{68}$ those on mechanical ventilation, ${ }^{69-72}$ renal transplantation, ${ }^{61}$ and other immunocompromised patients. ${ }^{7374}$

Bronchoalveolar lavage has also been used to acquire a relatively clean sample from the lower respiratory tract, and it allows sampling of a wider area of the lung. This, at least theoretically, should be more sensitive than the brush technique. In a prospective study of patients undergoing bronchoscopy ${ }^{7}$ there were 54 patients with no clinical evidence of bacterial pneumonia. The semiquantitative culture recovered $<10^{4} \mathrm{cfu} / \mathrm{ml}$ BAL fluid from 50 of the 54 patients $(93 \%)$, while none of the non-infected patients had $>10^{5} \mathrm{cfu} / \mathrm{ml}$ BAL fluid. In patients with a bacterial pneumonia not responding to antibiotics, 13 of $15(86 \%)$ had $>10^{5} \mathrm{cfu} / \mathrm{ml}$ and the remaining two grew between $10^{4}$ and $10^{5} \mathrm{cfu} / \mathrm{ml}$. The distinction between pneumonia and non-pneumonia on the basis of semiquantitative cultures has been confirmed by other groups. ${ }^{667576}$ In general, if the patient has $>10^{5} \mathrm{cfu} / \mathrm{ml}$ then he has pneumonia, but with $<10^{4} \mathrm{cfu} / \mathrm{ml}$ he does not. It is not known whether a protected BAL catheter improves the specificity of the procedure. ${ }^{77}$

Legionella and Nocardia are bacterial pathogens whose recovery from sputum is unusual. Bronchoscopy is a suitable method for diagnosing both of these pathogens. ${ }^{557879}$ Our experience with 11 patients with nocardial pneumonia showed that both bronchial washing and BAL could be diagnostic, and the organism was usually identified in fungal culture media. ${ }^{80}$ Legionella is best recovered from a non-selective, highly enriched charcoal media from the BAL fluid. ${ }^{79}$

\section{Conclusion}

Non-infectious causes of infiltrates and hypoxaemia that can be diagnosed by bronchoscopy have not been discussed. These include pulmonary haemorrhage, malignancy, and hypersensitivity reactions.

The use of bronchoscopy for diagnosing infection has become routine in pulmonary medicine. Each of the sampling techniques has a role for individual organisms, with some techniques having a wider range of success than others. Table 2 summarises the various pathogens found in the lower respiratory tract and the relative diagnostic value of each technique. Table 3 is a summary of the risk of infection, dependent on the underlying condition of the host. These two tables can be used as a guide to determine which specimens to obtain during bronchoscopy. For example, a transbronchial biopsy is of limited value in the initial assessment of ventilator associated pneumonia, while it may be necessary in the HIV infected patient in whom CMV pneumonitis is suspected.

Division of Pulmonary and

ROBERT P BAUGHMAN

Critical Care,

University of Cincinnati,

231 Bethesda Avenue ML 564,

Cincinnati

Ohio 45267-0564,

USA 
1 Stover DE, Zaman MB, Hajdu SI, Lange M, Gold J, Armstrong D. Bronchoalveolar lavage in the diagnosis of diffuse pulmonary infiltrates in the immunosuppressed host. Ann Intern Med 1984;101:1-7.

2 Hopkin JM, Young JA, Turney JH, Adu D, Michael J. Rapid diagnosis of obscure pneumonia in immunosuppressed renal patients by cytology of alveolar lavage fluid. Lancet 1983;ii:299-301.

3 Levin DC, Wicks AB, Ellis JH, Jr. Transbronchial lung biopsy via the fiberoptic bronchoscope. Am Rev Respir Dis 1974;110:4-12.

4 Broaddus C, Dake MD, Stulbarg MS, Blumenfeld W, Hadley WK, Golden $\mathrm{JA}$, et al. Bronchoalveolar lavage and transbronchial biopsy for the diagnosis of pulmonary infections in the acquired immunodeficiency syndrome. Ann Intern Med 1985;102:747-52.

5 Pereira W, Kovnat DM, Snider GL. A prospective cooperative study of complications following flexible fiberoptic bronchoscopy. Chest 1978;73:813-6.

6 Baughman RP, Dohn MN, Loudon RG, Frame PT. Bronchoscopy with bronchoalveolar lavage in tuberculosis and fungal infections. Chest 1991;99:92-7.

7 Thorpe JE, Baughman RP, Frame PT, Wesseler TA, Staneck JL. Bronchoalveolar lavage for diagnosing acute bacterial pneumonia. $\mathcal{F}$ Infect $D$ is 1987;155:855-61.

8 Zaman MK, Wooten OJ, Ballambettu S, Ankobiah W, Finch PJP, Kamholz SL. Rapid noninvasive diagnosis of Pneumocystis carinii from induced liquefied sputum. Ann Intern Med 1988;109:7-10.

9 Bigby TD, Margolskee D, Curtis JL, Michael PF, Sheppard D, Hadley WK, et al. The usefulness of induced sputum in the diagnosis of Pneumocystis carinii pneumonia in patients with the acquired immunodeficiency syndrome. Am Rev Respir Dis 1986;133:515-8.

10 Pitchenik AE, Ganjei P, Torres A, Evans DA, Rubin E, Baier H. Sputum examination for the diagnosis of Pneumocystis carinii pneumonia in the acquired immunodeficiency syndrome. Am Rev Respir Dis 1986;133:226-9.

11 Kovacs JA, $\mathrm{Ng}$ VL, Masur H, Leoung G, Hadley WK, Evans G, et al Diagnosis of Pneumocystis carinii pneumonia: improved detection in sputum with the use of monoclonal antibodies. $N$ Engl $\mathcal{f} \mathrm{Med}$

12 Jules-Elysee KM, Stover DE, Zaman MB, Bernard EM, White DA. Aerosolized pentamidine: effect on diagnosis and presentation of Pneumocystis carinii pneumonia. Ann Intern Med 1990;112:750-7.

$13 \mathrm{Gal}$ AA, Klatt EC, Koss MN, Strigle SM, Boylen CT. The effectiveness of bronchoscopy in the diagnosis of Pneumocystis carinii and cytomegalovirus pulmonary infections in acquired immunodeficiency syndrome. Arch Pathol Lab Med 1987;111:238-41.

14 Baughman RP, Strohofer SS, Clinton BA, Nickol AD, Frame PT. The use of an indirect fluorescent antibody test for detecting Pneumocystis carinii. Arch Pathol Lab Med 1989;113:1062-5.

15 Coleman DL, Dodek PM, Luce JM, Golden JA, Gold WM, Murray JF. Diagnostic utility of fiberoptic bronchoscopy in patients with Pneumocystis carinii pneumonia and the acquired immune deficiency syndrome. Am Rev Respir Dis 1983;128:795-9.

16 Stover DE, White DA, Romano PA, Gellene RA. Diagnosis of pulmonary disease in acquired immune deficiency syndrome (AIDS). Am Rev Respir Dis 1984;130:659-62.

17 Mones JM, Saldana MJ, Oldham SA. Diagnosis of Pneumocystis carini pneumonia: roentgenographic-pathologic correlates based on fiberoptic bronchoscopy specimens from patients with the acquired immunodeficiency syndrome. Chest 1986;89:522-6.

18 Sepkowitz KA, Telzak EE, Gold JWM, Bernard EM, Blum S, Carrow M, et al. Pneumothorax in AIDS. Ann Intern Med 1991;114:455-9.

19 McClellan MD, Miller SB, Parsons PE, Cohn DL. Pneumothorax with Pneumocystis carinii pneumonia in AIDS: incidence and clinical characteristics. Chest 1991;100:1224-8.

20 Golden JA, Hollander H, Stubarg MS, Gamsu G. Bronchoalveolar lavage as the exclusive diagnostic modality for Pneumocystis carinii pneumonia. Chest 1986;90:18-22.

21 Smith RL, El-Sadr WM, Lewis ML. Correlation of bronchoalveolar lavage cell populations with clinical severity of Pneumocystis carinii pneumonia. Chest 1988;93:60-4.

22 Mason GR, Hashimoto CH, Dickman PS, Foutty LF, Cobb CJ. Prognostic implications of bronchoalveolar lavage neutrophilia in patients with Pneumocystis carinii pneumonia and AIDS. Am Rev Respir Dis 1989;139:1336-42.

23 Baughman RP, Strohofer S, Colangelo G, Frame PT. Semiquantitative technique for estimating Pneumocystis carinii burden in the lung. $7 \mathrm{Clin}$ Microbiol 1990;28:1425-7.

24 Limper AH, Offord KP, Smith TF, Martin WJ II. Pneumocystis carini pneumonia: differences in lung parasite number and inflammation in patients with and without AIDS. Am Rev Respir Dis 1989;140:1204-9.
Colangelo G, Baughman RP, Dohn MN, Frame PT. Follow-up bronchoalveolar lavage in AIDS patients with Pneumocystis carinii pneumonia. $A m$ Rev Respir Dis 1991;143:1067-71.

26 Leoung GS, Feigal DW, Montgomery AB, Corkery K, Wardlaw L, Adams $\mathrm{M}$, et al. San Francisco County Community Consortium. Aerosolized pentamidine for prophylaxis against Pneumocystis carinii pneumonia. $N$ Engl f Med 1990;323:769-75.

27 Baughman RP, Dohn MN, Shipley R, Buchsbaum JA, Frame PT. Increased Pneumocystis carinii recovery from the upper lobes in pneumocystis pneumonia: the effect of aerosol pentamidine prophylaxis. Chest 1993;103:426-32.

28 Meduri GU, Stover DE, Greeno RA, Nash T, Zaman MB. Bilateral bronchoalveolar lavage in the diagnosis of opportunistic pulmonary bronchoalveolar lavage in the diag

29 Read CA, Cerrone F, Busseniers AE, Waldhorn RE, Lavelle JP, Pierce PF. Differential lobe lavage for diagnosis of acute Pneumocystis carinii pneumonia in patients receiving prophylactic aerosolized pentamidine therapy. Chest 1993;103:1520-3.

30 Levine SJ, Kennedy D, Shelhamer JH, Kovacs A, Feuerstein IM, Gill VJ, et al. Diagnosis of Pneumocystis carinii pneumonia by multiple lobe, sitedirected bronchoalveolar lavage with immunofluorescent monoclonal antibody staining in human immunodeficiency virus-infected patients receiving aerosolized pentamidine chemoprophylaxis. Am Rev Respir Dis 1992;146:838-43.

31 Peterson PK, Balfour HH, Marker SC, Fryd DS, Howard RJ, Simmons RL. Cytomegalovirus disease in renal allograft recipients: a prospective study of the clinical features, risk factors and impact on renal transplantation. Medicine 1980;59:283-300.
32 Chan CK, Hyland RH, Hutcheon MA. Pulmonary complications following bone marrow transplantation. Clin Chest Med 1990;11:323-32.

33 Cordonnier C, Bernaudin J-F, Bierling P, Huet Y, Vernant J-P. Pulmonary complications occurring after allogeneic bone marrow transplantation. A study of 130 consecutive transplanted patients. Cancer 1986;58:1047-54.

34 Buhles WC, Mastre BJ, Tinker AJ, Strand V, Koretz SH. Syntex Collaborative Ganciclovir Treatment Study Group. Ganciclovir treatment of lifeor sight-threatening cytomegalovirus infection: experience in $314 \mathrm{immu}$ nocompromised patients. Rev Infect Dis 1988;10:S495-506.

35 Emanuel D, Peppard J, Stover D, Gold J, Armstrong D, Hammerling U. Rapid immunodiagnosis of cytomegalovirus pneumonia by bronchoalveolar lavage using human and murine monoclonal antibodies. Ann Inter Med 1986;104:476-81.

36 Martin WJ II, Smith TF. Rapid detection of cytomegalovirus in bronchoalveolar specimens by a monoclonal antibody method. f Clin Microbiol 1986;23:1006-8.

37 Gleaves CA, Smith TF, Shuster EA, Pearson GR. Comparison of standard tube and shell vial cell culture techniques for the detection of cytomegalovirus in clinical specimens. F Clin Microbiol 1985;21:217-21.

38 Cordonnier C, Escudier E, Nicolas J-C, Fluery J, Deforges L, Ingrand D, $e t$ al. Evaluation of three assays on alveolar lavage fluid in the diagnosis of cytomegalovirus pneu

39 Dauber JH, Paradis IL Duncan SR, Yousem SA. Pulmonary transplantation. In: Baughman RP, ed. Bronchoalveolar lavage. St Louis: Mosby Year Book, 1992:64-89.

40 Thompson AB, Rickard KA, Shaw BW, Wood RP, Williams L, Burnet $\mathrm{DA}$, et al. Pulmonary complications and disease severity in adult liver transplant recipients. Transplant Proc 1988;20:646-9.

41 Keenan RJ, Lega ME, Dummer JS, Paradis IL, Dauber JH, Rabinowich $\mathrm{H}$, et al. Cytomegalovirus serologic status and postoperative infection correlates with risk of developing chronic rejection after pulmonary transplantation. Transplantation 1991;51:433-8.

42 Johnson PC, Hogg KM, Sarosi GA. The rapid diagnosis of pulmonary infections in solid organ transplant recipients. Semin Resp Infect 1990;5:2-9.

43 Bozzette SA, Arcia J, Bartok AE, McGlynn LM, McCutchan JA, Richman $\mathrm{DD}$, et al. Impact of Pneumocystis carinii and cytomegalovirus on the course and outcome of atypical pneumonia in advanced human immunodeficiency virus disease. $\mathcal{F}$ Infect Dis 1992;165:93-8.

44 Millar AB, Patou G, Miller RF, Grundy JE, Katz DR, Weller IV, et al. Cytomegalovirus in the lungs of patients with AIDS. Respiratory pathogen or passenger? Am Rev Respir Dis 1990;141:1474-7.

45 Miles PR, Baughman RP, Linnemann CC, Jr. Cytomegalovirus in the bronchoalveolar lavage fluid of patients with AIDS. Chest 1990;97:10726.

46 Wallace JM, Hannah J. Cytomegalovirus pneumonitis in patients with AIDS: findings in an autopsy series. Chest 1987;92:198-203.

47 King C, Wacker W, Baughman RP, et al. CMV detection in cytologic and histologic specimens, using direct-labeled DNA probes and in situ hybridization. Presented at the US and Canadian Academy of Pathology, Boston, 1990.

48 Ramsey PG, Fife KH, Hackman RC, Meyers JD, Corey L. Herpes simplex virus pneumonia. Ann Intern Med 1982;97:813-20.

49 Tuxen DV, Cade JF, McDonald MI, Buchanan MRC, Clark RJ, Pain MCF. Herpes simplex virus from the lower respiratory tract in adul respiratory distress syndrome. Am Rev Respir Dis 1982;126:416-9.

50 Tuxen DV, Wilson JW, Cade JF. Prevention of lower respiratory herpe simples virus infection with acyclovir in patients with the adult respiratory distress syndrome. Am Rev Respir Dis 1987;136:402-5.

51 Connolly MG, Baughman RP, Dohn MN, Linnemann CC. Prospective study of bronchoscopy with bronchoalveolar lavage for the isolation of viruses. Am Rev Respir Dis 1992;145:A544.

52 Neff TA. Bronchoscopy and Bactec for the diagnosis of tuberculosis: state of the art, or a brief dissertation on the efficient search for the tubercle bacillus? Am Rev Respir Dis 1986;133:962.

53 Russell MD, Torrington KG, Tenholder MF. A ten-year experience fiberoptic bronchoscopy for mycobacterial isolation: impact of the Bactec system. Am Rev Respir Dis 1986;133:1069-71.

54 Wallace JM, Deutsch AL, Harrell JH, Moser KM. Bronchoscopy and transbronchial biopsy in evaluation of patients with suspected active tuberculosis. Am $\mathscr{F}$ Med 1981;70:1189-94.

55 Malabonga VM, Basti J, Kamholz SL. Utility of bronchoscopic sampling techniques for cryptococcal disease in AIDS. Chest 1991;99:370-2.

56 Baughman RP, Kim CK, Bullock WE. Comparative diagnostic efficacy of bronchoalveolar lavage, transbronchial biopsy, and open-lung biopsy in experimental pulmonary histoplasmosis. F Infect Dis 1986;153:376-7.

57 George RB, Jenkinson SG, Light RW. Fiberoptic bronchoscopy in th diagnosis of pulmonary fungal and nocardial infections. Chest 1978;73:33-6.

58 Baughman RP, Rhodes JC, Dohn MN, Henderson H, Frame PT. Detection of cryptococcal antigen in bronchoalveolar lavage fluid: a prospective study of diagnostic utility. Am Rev Respir Dis 1992;145:1226-9.

59 Wheat LJ, Kohler RB, Tewari RP. Diagnosis of disseminated histoplasmosis by detection of Histoplasma capsulatum antigen in serum and urine specimens. $N$ Engl $\mathcal{F}$ Med 1986;314:83-8.

60 Heurlin N, Lönnqvist B, Tollemar J, Ehrnst A. Fiberoptic bronchoscopy for diagnosis of opportunistic pulmonary infections after bone marrow transplantation. Scand 7 Infect Dis 1989;21:359-66.

61 Hedemark LL, Kronenberg RS, Rasp FL, Simmons RL, Peterson PK. The value of bronchoscopy in establishing the etiology of pneumonia in renal transplant recipients. Am Rev Respir Dis 1982;126:981-5.

62 Bartlett JG, Alexander J, Mayhew J, Sullivan-Sigler N, Gorbach SL. Should fiberoptic bronchoscopy aspirates be cultured? Am Rev Respir Dis 1976;114:73-8.

63 Wimberley N, Faling LJ, Bartlett JG. A fiberoptic bronchoscopy technique to obtain uncontaminated lower airway secretions for bacterial culture. Am Rev Respir Dis 1979;119:337-43.

64 Chauncey JB, Lynch JP III, Hyzy RC, Toews GB. Invasive techniques in the diagnosis of bacterial pneumonia in the intensive care unit. Semin Resp Infect 1990;5:215-25.

65 Winterbauer RH, Hutchinson JF, Reinhardt GN, Sumida SE, Dearden B, Thomas CA, et al. The use of quantitative cultures and antibody coating Am Rev Respir Dis 1983;128:98-103. 
66 Baselski VS, El-Torky M, Coalson JJ, Griffin JP. The standardization of criteria for processing and interpreting laboratory specimens in patients with suspected ventilator-associated pneumonia. Chest 1992;102:571S9S.

67 Örtqvist A, Kalin M, Lejdeborn L, Lundberg B. Diagnostic fiberoptic bronchoscopy and protected brush culture in patients with communityacquired pneumonia. Chest 1990;97:576-82.

68 Kirkpatrick MB, Haynes J Jr, Bass JB Jr. Results of bronchoscopically obtained lower airway cultures from adult sickle cell disease patients with the acute chest syndrome. Am $f$ Med 1991;90:206-10.

69 Chastre J, Fagon J-Y, Soler P, Bornet M, Domart Y, Trouillet J-L, et al. Diagnosis of nosocomial bacterial pneumonia in intubated patients undergoing ventilation: comparison of the usefulness of bronchoalveolar lavage going ventilation: comparison of the usefulness of bronchoalveol
and the protected specimen brush. Am $\mathcal{M}$ Med 1988;85:499-506.

70 Guerra LF, Baughman RP. Use of bronchoalveolar lavage to diagnose bacterial pneumonia in mechanically ventilated patients. Crit Care Med 1990;18:169-73.

71 Chastre J, Viau F, Brun P, Pierre J, Dauge M-C, Bouchama A, et al. Prospective evaluation of the protected specimen brush for the diagnosis of pulmonary infections in ventilated patients. Am Rev Respir Dis 1984;130:924-9.

72 Torres A, Puig-De la Bellacasa J, Rodriguez-Roisin R, Jimenez de Anta MT, Agusti-Vidal A Diagnostic value of telescoping plugged catheters in mechanically ventilated patients with bacterial pneumonia using the Metras catheter. Am Rev Respir Dis 1988;138:117-20.
73 Xaubet A, Torres A, Marco F, Puig-De la Bellacasa J, Faus R, Agusti-Vidal A. Pulmonary infiltrates in immunocompromised patients: diagnostic value of telescoping plugged catheter and bronchoalveolar lavage. Chest 1989;95:130-5.

74 Ferrer M, Torres A, Xaubet A, Puig-De la Bellacasa J, Agusti C, Gonzalez $\mathrm{J}$, et al. Diagnostic value of telescoping plugged catheters in HIV-infected patients with pulmonary infiltrates. Chest 1992;102:76-83.

75 Middleton R, Broughton WA, Kirkpatrick MB. Comparison of four methods for assessing airway bacteriology in intubated, mechanically ventilated patients. Am $\Im$ Med Sci 1992;304:239-45.

76 Pugin J, Auckenthaler R, Mili N, Janssens J-P, Lew PD, Suter PM. Diagnosis of ventilator-associated pneumonia by bacteriologic analysis of bronchoscopic and nonbronchoscopic "blind" bronchoalveolar lavage fluid. Am Rev Respir Dis 1991;143:1121-9.

77 Meduri GU, Beals DH, Maijub AG, Baselski V. Protected bronchoalveolar lavage: a new bronchoscopic technique to retrieve uncontaminated distal airway secretions. Am Rev Respir Dis 1991;143:855-64.

78 Thomas P, Lang AP, Fong IW. Diagnosis of Legionnaires' disease from transbronchial lung biopsy using the fiberoptic bronchoscope. Can Med Assoc $\mathcal{F}$ 1980;122:794-6.

79 Kohorst WR, Schonfeld SA, Macklin JE, Whitcomb ME. Rapid diagnosis of Legionnaire's disease by bronchopulmonary lavage. Chest 1983;84:186-90.

80 Connolly MG, Baughman RP, Dohn MN. The utility of bronchoscopy in diagnosing Nocardia asteroides. Am Rev Respir Dis 1991;143:A112. 